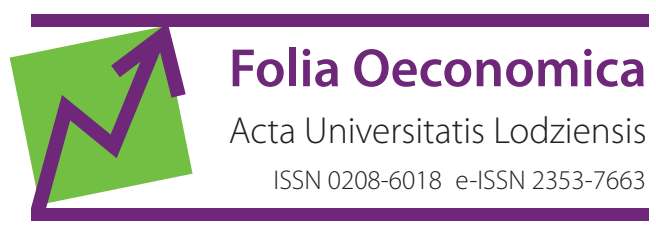

www.czasopisma.uni.lodz.pl/foe/

6(339) 2018

DOI: http://dx.doi.org/10.18778/0208-6018.339.07

\title{
Justyna Kłobukowska
}

Uniwersytet Mikołaja Kopernika w Toruniu, Wydział Nauk Ekonomicznych i Zarządzania,

Katedra Zarządzania Finansami, jklobukowska@umk.pl

\section{Społecznie odpowiedzialne inwestowanie} jako innowacja na rynku finansowym w Polsce w dobie finansjalizacji - stan obecny i perspektywy

\begin{abstract}
Streszczenie: Głównym celem artykułu jest identyfikacja elementów wyróżniających społecznie odpowiedzialne inwestowanie (SRI) jako innowację na rynku finansowym oraz przedstawienie perspektyw rozwoju SRI w Polsce. W opracowaniu omówiono definiowanie zrównoważonego rynku finansowego i społecznie odpowiedzialnego inwestowania oraz przeanalizowano SRI pod kątem cech charakteryzujących innowacje finansowe. Wybrane aspekty SRI, takie jak RESPECT Index czy ekologiczne obligacje, stanowią przykład innowacji na polskim rynku finansowym. W ramach analizy perspektyw społecznie odpowiedzialnego inwestowania w Polsce zaprezentowano wyniki autorskich badań empirycznych zrealizowanych w 2017 roku według metody delfickiej, które wskazują na wolny wzrost SRI w okresie najbliższych pięciu lat.
\end{abstract}

Słowa kluczowe: innowacja finansowa, społecznie odpowiedzialne inwestowanie, zielone obligacje, RESPECT Index, finansjalizacja

JEL: M14, Q01, 016 


\section{Wprowadzenie}

Zawirowania na rynku finansowym, mimo niemal dekady od ich historycznej eksplozji, nieustannie przypominają o tym, jak niebezpieczna w skutkach staje się sytuacja, w której alokacją zasobów pieniężnych w gospodarce rządzą chciwość i spekulacje. Rolą rynku finansowego jest umożliwienie spotkania między równymi sobie stronami: poszukującymi kapitału i dysponentami nadwyżek finansowych. Liczne publikacje i dyskusje powinny świadczyć o tym, że wnioski z ostatniego kryzysu finansowego zostały wyciągnięte. Jednakże analiza danych na poziomie międzynarodowym, pochodzących z sektora finansowego i gospodarki realnej, jest alarmująca. Pogłębianie się zjawiska finansjalizacji powinno stanowić impuls do ponownej redefinicji roli rynku finansowego i przeglądu narzędzi, w tym produktów finansowych, które wykorzystywane są w ramach wspierania innowacyjnego rozwoju przedsiębiorstw.

Niejako równolegle zaobserwować można wzrost aktywności przedsiębiorstw oraz inwestorów uwzględniających w realizowanych działaniach kryteria pozafinansowe. Przedsiębiorstwa opierają swoje strategie biznesowe na idei społecznej odpowiedzialności biznesu (Corporate Social Responsibility - CSR), chociażby wdrażając liczne społecznie odpowiedzialne innowacje. $Z$ kolei instytucje finansowe oraz pozostali inwestorzy wyszukują takich form inwestycji, które są zgodne z kryteriami ESG (Environment, Social, Governance: czynniki środowiskowe, społeczne, zarządcze) lub SEE (Social, Environment, Ethical: czynniki społeczne, środowiskowe, etyczne). Wzrost oferty społecznie odpowiedzialnych produktów finansowych stanowi odpowiedź na trend, w którym zrównoważony rozwój staje się determinantą innowacyjnych rozwiązań w sektorze przedsiębiorstw i w sektorze finansowym, czego przykładem jest rozwój społecznie odpowiedzialnego inwestowania (Socially Responsible Investment - SRI).

Celem niniejszego artykułu jest identyfikacja elementów wyróżniających społecznie odpowiedzialne inwestowanie jako innowację na rynku finansowym oraz przedstawienie perspektyw rozwoju społecznie odpowiedzialnego inwestowania w Polsce.

Realizacja celu głównego będzie odbywać się na dwóch płaszczyznach. Po pierwsze - teoretycznej, gdyż zdefiniowania wymagają pojęcia zrównoważonego rynku finansowego oraz społecznie odpowiedzialnego inwestowania jako najszerzej popularyzowanego współcześnie kierunku inwestowania w zakresie etycznych finansów. Bazując na autorskiej definicji, przedstawione zostaną wybrane przykłady wdrażania na polskim rynku finansowym innowacyjnych rozwiązań z zakresu CSR.

Część empiryczna artykułu opiera się na wynikach badań własnych, przeprowadzonych metodą delficką wśród ekspertów rynku finansowego i społecznie 
odpowiedzialnego biznesu w Polsce 1 . Ponadto zastosowano takie metody badawcze, jak: indukcja, metoda porównawcza, krytyczna analiza literatury i raportów wiodących instytucji z zakresu CSR oraz SRI.

\section{Społecznie odpowiedzialne inwestowanie jako innowacja na rynku finansowym w dobie finansjalizacji}

Uwzględnianie kryteriów pozafinansowych podczas podejmowania decyzji na rynku finansowym to główna cecha charakterystyczna zrównoważonych finansów. Analogicznie do koncepcji zrównoważonego rozwoju finansowanie wzrostu gospodarczego ma się odbywać w oparciu o czynniki ekologiczne, społeczne i ekonomiczne w perspektywie długoterminowej oraz $\mathrm{w}$ duchu sprawiedliwości międzypokoleniowej w dostępie do zasobów materialnych i niematerialnych. Model biznesowy sektora finansowego, który opiera się na podejściu ściśle związanym z koncepcją społecznej odpowiedzialności biznesu oraz etyki biznesu, wspiera zrównoważony rozwój gospodarki, ale również prowadzi do modyfikacji procesów zachodzących na rynku finansowym.

Efektem tych zmian jest zrównoważony rynek finansowy, nazywany również społecznie odpowiedzialnym rynkiem finansowym. W takim ujęciu definiowany jest jako „ogół stosunków zachodzących pomiędzy uczestnikami rynku, w których czynniki etyczne, społeczne i środowiskowe na równi z czynnikami ekonomicznymi determinują podejmowanie decyzji zakupowych i sprzedażowych dotyczących produktów oraz usług finansowych" (Kłobukowska, 2017: 108). Konsekwencją tych decyzji jest dbałość o wzrost i rozwój gospodarczy z poszanowaniem praw obecnych i przyszłych pokoleń. Przedstawiona w tej postaci definicja jest wyrazem wkładu w szeroko dyskutowany problem rozrostu finansów w sensie ilościowym, a także zmian, które mają charakter jakościowy.

Finansjalizacja określana jest w literaturze jako rozrost finansów w stosunku do wytworów gospodarki realnej, przez co stan równowagi nie może być zachowany. W rozumieniu G. Epsteina (2001: 3) jej występowanie związane jest bezpośrednio ze wzrostem wpływu rynków finansowych, instytucji finansowych oraz motywów finansowych na gospodarkę w procesie podejmowania decyzji. W 1990 roku globalna wartość wyemitowanych instrumentów finansowych i zdeponowanych w bankach środków finansowych była dwukrotnie większa niż wartość wytworzonego PKB, a w 2007 roku była to już czterokrotność. Z kolei w 2014 roku globalne

${ }^{1}$ Przygotowanie i realizacja badania odbyły się na podstawie wnikliwych studiów literatury przedmiotu dotyczącej metodyki badań (m.in. Antoszkiewicz, 1990; Hsu, Sandford, 2007). 
aktywa rynków finansowych były wyceniane na poziomie 294000 bln USD, a globalny PKB osiągnął wartość około 77609 bln USD (EconomyWatch, 2017).

Innym objawem finansjalizacji jest wzrost kosztów finansowych korzystania z kapitału i jednocześnie wzrost znaczenia wskaźników finansowych w ocenie wartości przedsiębiorstw (Gregorczyk, 2015: 60). Sektor finansowy wdrożył produkty i usługi finansowe oparte na dźwigni finansowej, przez co są one obarczone wysokim ryzykiem inwestycyjnym. Skutki takiego zaangażowania unaocznił ostatni kryzys finansowy.

$\mathrm{Z}$ kolei nieco alternatywnie do tradycyjnego nurtu na globalnym rynku finansowym rozwija się inwestowanie społecznie odpowiedzialne. W literaturze przedmiotu na temat społecznie odpowiedzialnego inwestowania publikowane były prace zróżnicowane pod względem odniesienia do czynników pozaekonomicznych czy motywacji inwestorów (Schueth, 2003; Gollier, Pouget, 2012). Wiele badań koncentrowało się na dyskusji o efektywności społecznie odpowiedzialnych inwestycji, między innymi pod względem wybranej strategii inwestycyjnej (Statman, 2006), wpływu na wzrost wartości spółek (Gompers, Ishii, Metrick, 2003) czy porównania SRI z nieetycznymi inwestycjami (Hong, Kacperczyk, 2009). Społecznie odpowiedzialne inwestowanie traktowane jest głównie jako „strategia inwestowania ukierunkowana na jednoczesne maksymalizowanie stopy zwrotu z zainwestowanego kapitału (zysków finansowych) i dobra społecznego (społecznych i ekologicznych przekonań i oczekiwań)" (Jędrych, 2013: 195).

W jednej z pierwszych formalnych definicji, autorstwa A. Domini i P. Kindera z 1983 roku, termin $S R I$ wyjaśniono jako ,wcielenie społecznych i etycznych kryteriów inwestora do procesu podejmowania decyzji inwestycyjnych" (Kinder, 2005: 4), a R. Sparkes scharakteryzował SRI jako „pewien rodzaj filozofii inwestycyjnej, łączącej ze sobą zarówno kryteria finansowe, jak i pozafinansowe" (Sparkes, 2002: 22). Inną propozycję, wypracowaną na podstawie szerokich badań literaturowych, stanowi autorska definicja SRI nawiązująca do wyraźnych cech umożliwiających określenie społecznie odpowiedzialnego inwestowania innowacją na rynku finansowym. Zakłada się, że społecznie odpowiedzialne inwestowanie to proces inwestycyjny polegający na zaangażowaniu środków finansowych inwestora, koncentrujący się na czynnikach SEE (Social, Environment, Ethical) i/lub ESG (Environment, Social, Governance) w celu osiągnięcia pożądanych efektów finansowych oraz pozafinansowych za pomocą specjalnych strategii inwestycyjnych.

Należy przypomnieć, iż pojęcie innowacji, rozumianej jako implementacja do praktyki nowego rozwiązania, wprowadził do światowej literatury ekonomicznej J. A. Schumpeter w 1912 roku (Schumpeter, 1960). Inny ekonomista - P. Tufano - traktuje innowację jako proces, podczas którego prywatne podmioty próbują różnicować swoje produkty i usługi w odpowiedzi na zmiany w gospodarce - zarówno o charakterze nagłym, jak i stopniowym (Tufano, 2003: 2-4). Z ko- 
lei według W.S. Frame’a i L.J. White’a innowacja finansowa jest czymś nowym, co ma wpływ na obniżenie kosztów czy ryzyka i dostarcza nowy lub ulepszony produkt, usługę, która jest bardziej dopasowana do potrzeb uczestników systemu finansowego (Frame, White, 2004). Na bazie przywołanych podejść teoretycznych społecznie odpowiedzialne inwestowanie może być uznane za innowację na rynku finansowym, a zarazem stanowić wyzwanie w kontekście zaprezentowanego zjawiska finansjalizacji.

Społecznie odpowiedzialne inwestowanie przejawia cechy innowacji produktowej, procesowej i organizacyjnej (rysunek 1). Szczególnie wyraźnymi cechami SRI jako innowacji jest perspektywa długoterminowa i oparcie wszelkich procesów na czynnikach ESG. W związku z szeroką gamą produktów tradycyjnych, do których w procesie tworzenia zaimplementować można kryteria ESG, można wskazać zupełnie nowe, dotychczas nieistniejące rozwiązania. Wśród przykładów należy wskazać chociażby „zielone” produkty inwestycyjne, takie jak obligacje ekologiczne oraz kredyty proekologiczne (Dziawgo, 1998), społecznie odpowiedzialne fundusze inwestycyjne czy też oparte na podejściu społecznym produkty z zakresu mikrofinansów oraz obligacje społeczne (International Finance Corporation, 2017).

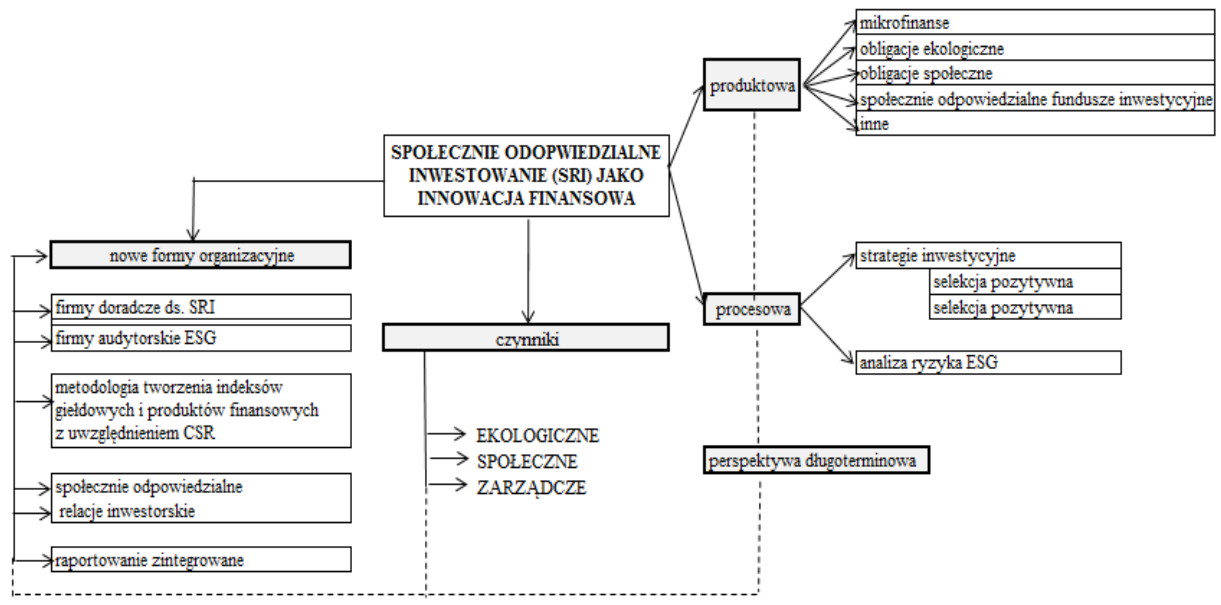

Rysunek1. Społecznie odpowiedzialne inwestowanie jako innowacja finansowa Źródło: opracowanie własne

Potwierdzenie, że społecznie odpowiedzialne inwestowanie to również innowacja procesowa, wynika $\mathrm{z}$ wykorzystywania w procesie podejmowania decyzji inwestycyjnych różnych strategii inwestycyjnych. Kluczowy jest ich podstawowy podział na selekcję negatywną (bazującą na wykluczeniu z inwestycji określonych branż lub krajów) oraz selekcję pozytywną (promowanie wyróżniających się spółek w zakresie CSR, np. przez strategię ,najlepszy z najlepszych", inwestycje tematyczne, inwestycje z wpływem itp.) (Kłobukowska, 2014: 80-83). 
Pod względem nowych form organizacyjnych należy wyróżnić zmiany w zakresie specjalizacji zawodowych, które są wynikiem zainteresowania kwestiami SRI. Zarówno na etapie tworzenia, jak i oferowania produktów SRI niezbędne jest wsparcie audytorów oraz doradców, a po stronie przedsiębiorstw - osób raportujących dane pozafinansowe oraz specjalistów do spraw relacji inwestorskich. Takie osoby powinny posiadać niezbędne kompetencje zarówno w obszarze danych finansowych spółki, jak i jej wyników pozafinansowych w kontaktach z inwestorami i innymi interesariuszami.

Społecznie odpowiedzialne inwestowanie dotyka nie tylko kwestii stricte gospodarczych, ale jest również kanałem dostarczania kapitału na cele środowiskowe oraz społeczne. Cele i zakres alokacji pieniądza są tu o wiele szersze niż przy innych innowacjach finansowych. Produkty inwestycyjne powstające w oparciu o SRI nie generują dodatkowego ryzyka, ale zmniejszają go przez uwzględnienie większej liczby kryteriów oceny danych przedsięwzięć.

Przedsiębiorstwa oraz inne organizacje w ramach swojej społecznej odpowiedzialności wprowadzają międzynarodowe standardy i raportują działalność CSR (Carrots \& Sticks..., 2016). Coraz częściej stosują raportowanie zintegrowane, które należy rozumieć jako dostarczanie raportu finansowego i raportu danych pozafinansowych $\mathrm{w}$ jednym dokumencie - jako holistycznej informacji o funkcjonowaniu i wartości przedsiębiorstwa. Dodatkowo ich oferta produktowa odpowiada komplementarnie na potrzeby przedsiębiorstw wprowadzających społecznie odpowiedzialne innowacje (Kłobukowska, 2015: 62-70).

\section{Społecznie odpowiedzialne inwestowanie w Polsce - aktualny obraz rynku}

Za fundament rynku społecznie odpowiedzialnego inwestowania w Polsce należy uznać ład korporacyjny, którego ważność wymusiło wdrożenie prawa wspólnotowego po akcesji Polski do Unii Europejskiej w 2004 roku. Spółki publiczne notowane na GPW w Warszawie zobowiązane zostały do transparentnego informowania w swoich rocznych sprawozdaniach finansowych o stosowanej polityce w zakresie corporate governance. Po raz pierwszy rynek społecznie odpowiedzialnego inwestowania w Polsce został uwzględniony w raporcie Eurosif w 2010 roku. Wartość rynku w 2009 roku oszacowano na około 1 mld EUR, co stanowiło około 0,3\% całkowitej wartości zarządzanych aktywów (Eurosif, 2010: 45).

Do 2013 roku selekcja negatywna była najczęściej wykorzystywana w Polsce w procesach inwestycyjnych z uwzględnieniem kryteriów środowiskowych, społecznych i ładu korporacyjnego. Wartość zaangażowanych aktywów w 2011 roku oszacowano na 2,72 mld PLN, a w 2013 roku już na 4,40 mld PLN (tabela 1). 
Tabela 1. Przekrój polskiego rynku społecznie odpowiedzialnego inwestowania w latach 2009-2015 ze względu na strategię (dane w mln PLN)

\begin{tabular}{|l|r|r|r|r|}
\hline \multicolumn{1}{|c|}{ Strategia } & $\mathbf{2 0 0 9}$ & $\mathbf{2 0 1 1}$ & $\mathbf{2 0 1 3}$ & $\mathbf{2 0 1 5}$ \\
\hline Najlepsze w swojej klasie & 0 & 56 & 13 & 638 \\
\hline Inwestycje tematyczne & 0 & 0 & 0 & 883 \\
\hline Selekcja na bazie norm & 8 & 56 & 3209 & 650 \\
\hline Integracja czynników ESG & 0 & 0 & 0 & 0 \\
\hline Zaangażowanie i głosowanie & 0 & 0 & 2400 & 0 \\
\hline Negatywna selekcja & 4450 & 2716 & 4402 & 650 \\
\hline Inwestycje społeczne & 0 & 0 & 0 & 8 \\
\hline
\end{tabular}

Źródło: opracowanie własne na podstawie: Eurosif, 2010: 45; 2012: 51; 2014: 55; 2016: 85

Głównymi kryteriami wykluczenia były sektory powiązane z energią nuklearną, produkcją i sprzedażą broni, alkoholu, tytoniu oraz hazardem. Po wspomnianym okresie popularność inwestorów zaczęły zdobywać inne strategie pozytywne, takie jak strategia zaangażowania, integracji czynników ESG czy „,najlepsze w swojej klasie". W 2015 roku po raz pierwszy strategia pozytywna, a dokładniej inwestowanie tematyczne w zakresie zrównoważonego rozwoju, była najpopularniejsza na polskim rynku. Rozszerzenie liczby strategii inwestycyjnych wykorzystywanych w procesach inwestycyjnych należy uznać za pozytywny sygnał płynący z rynku i przemawiający na korzyść ogólnej charakterystyki rynku SRI w Polsce.

Inną odpowiedzią na światowy trend popularyzacji spółek społecznie odpowiedzialnych było ustanowienie indeksu RESPECT przez Giełdę Papierów Wartościowych w Warszawie w 2009 roku. Był to pierwszy indeks dedykowany spółkom CSR w Europie Środkowo-Wschodniej. W jego skład wchodzą tylko spółki notowane na głównym parkiecie GPW w Warszawie. Badanie społecznej odpowiedzialności spółek wchodzących w skład indeksu odbywa się w trzech etapach. Dwa pierwsze polegają na analizie ogólnodostępnych informacjach o działalności przedsiębiorstw, a etap trzeci bazuje na wynikach badania ankietowego, w którym uczestniczą zainteresowane spółki. Liczba spółek w RESPECT Index jest zmienna. Po ostatniej rewizji w grudniu 2017 roku w jego skład wchodzi 28 spółek (GPW, 2017).

Novum na polskim rynku finansowym jest emisja rządowych obligacji ekologicznych. Zielone obligacje zostały wyemitowane 12 grudnia 2016 roku z terminem wykupu na 20 grudnia 2021 roku na kwotę 750 mln EUR. Była to pierwsza emisja przeprowadzona przez emitenta rządowego na świecie (Money, 2016). Tym samym polski rząd przyczynił się do wprowadzenia nowego segmentu na rynku ekologicznych obligacji w kategorii sovereign. W marcu 2017 roku Climate Bonds Initiative (na uroczystości zorganizowanej wspólnie przez International Capital Market Association oraz City of London) przyznał polskiemu rządowi nagrodę w kategorii „Green Bonds Pioneer Awards” (Ambasada RP w Londynie, 2017). 
Z kolei organizacja OECD na przykładzie Polski ma zamiar rozpropagować tę formę pozyskiwania kapitału wśród innych krajów.

Rentowność wyemitowanych obligacji wyniosła $0,63 \%$, przy rocznym kuponie na poziomie $0,5 \%$. Pod względem instytucjonalnym niemal połowę obligatariuszy stanowiły fundusze inwestycyjne, natomiast geograficznie inwestorzy pochodzili z krajów europejskich z dominacją krajów niemieckojęzycznych. Strukturę instytucjonalną przedstawia rysunek 2 .

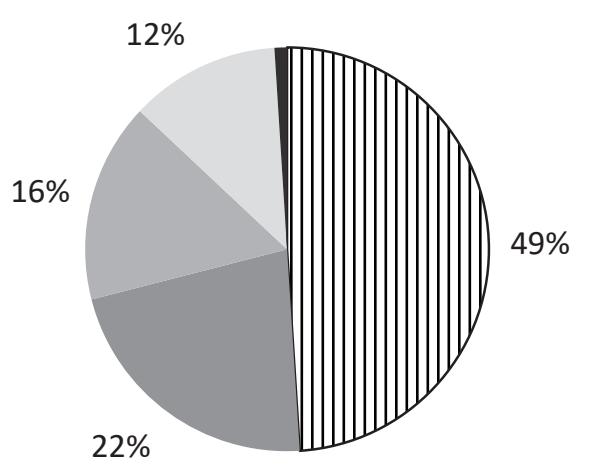

凹 fundusze inwestycyjne

- banki

instytucje ubezpieczeniowe i fundusze emerytalne

banki centralne i instytucje publiczne

घinne

Rysunek 2. Struktura instytucjonalna nabywców rządowych obligacji ekologicznych Źródło: opracowanie własne na podstawie: Ministerstwo Finansów, 2016

Głównym celem emisji było finansowanie projektów korzystnie wpływających na środowisko naturalne, zgodnych z wymogami Green Bond Framework, który został opracowany przez Ministerstwo Finansów na podstawie międzynarodowych standardów ICMA Green Bond Principles. Plany rządu uwzględniają kolejne emisje produktów tego typu (Ministerstwo Finansów, 2016).

Inną interesującą gamę produktów społecznie odpowiedzialnych na polskim rynku finansowym tworzą fundusze inwestycyjne. Pionierem oferty funduszy SRI było TFI SKOK SA, które wprowadziło dwa fundusze: SKOK Etyczny 1 SFIO (pierwsza wycena w 2008 r.) oraz SKOK Etyczny 2 (pierwsza wycena w 2010 r.). Podczas zarządzania tymi portfelami jako nadrzędna stosowana jest negatywna selekcja. Inne fundusze inwestycyjne SRI w Polsce mają charakter sektorowy, a w nomenklaturze SRI można je określić mianem inwestycji tematycznych, dotyczących głównie projektów związanych z ochroną środowiska naturalnego. Oferta na rynku polskim nie jest jednak znacząca, a część z nich udostępniana jest przez podmioty zagraniczne i nominowana w walucie obcej (Jedynak, 2016: 36-37). Nowe proponowane rozwiązania inwestycyjne, uwzględniające sektor energii odnawialnej, ochrony wód i przyrody, w tym leśnictwa, stanowią ważny krok w dołączaniu do globalnego trendu zmieniającego charakter rynku finansowego w Polsce w kierunku zrównoważonego rozwoju. 


\section{Perspektywy społecznie odpowiedzialnego inwestowania na polskim rynku finansowym w świetle badań własnych}

W celu uzyskania aktualnego spojrzenia na kwestie rozwoju inwestowania na polskim rynku finansowym poczyniono autorskie badanie perspektyw społecznie odpowiedzialnego inwestowania w naszym kraju. Badanie główne, w dwóch rundach, zrealizowano według metody delfickiej w okresie od stycznia do kwietnia 2017 roku. Na zaproszenie do udziału w badaniu pozytywnie odpowiedziało szesnastu ekspertów - wśród nich znaleźli się przedstawiciele środowiska naukowego, praktycy rynku kapitałowego oraz społecznej odpowiedzialności biznesu.

Kwestią wyjściową przeprowadzonego badania było określenie obecnych tendencji na rynku finansowym w Polsce dotyczących społecznie odpowiedzialnego inwestowania. Za dominujący obszar społecznie odpowiedzialnego inwestowania na polskim rynku finansowym eksperci uznali zdecydowanie ład korporacyjny (50\% wskazań). Otrzymane wyniki wskazują na powielenie typowej charakterystyki rynków rozwijających się w zakresie społecznie odpowiedzialnego inwestowania. Ich podstawą jest wspieranie dobrowolnego uwzględniania kwestii zarządczych oraz ekologicznych w procesach inwestycyjnych i to one dominują w początkowych fazach rozwoju społecznie odpowiedzialnego inwestowania. Podobnie jest w Polsce. Jak wspominano wcześniej, bodźcem implementacji SRI było właśnie przedstawienie korzyści zwiększonej transparentności przedsiębiorstw w zakresie wdrażania dobrych praktyk ładu korporacyjnego.

W dalszej części przeprowadzonego badania dokonano próby określenia czynników wpływających na wzrost popytu ze strony inwestorów na społecznie odpowiedzialne produkty inwestycyjne w Polsce. Uzyskane wyniki, zaprezentowane na rysunku 2, pozwoliły określić, iż najważniejszym czynnikiem jest wyższa stopa zwrotu niż z tradycyjnych produktów inwestycyjnych (22\% wskazań).

Za istotne czynniki angażujące inwestorów na rynku SRI uznano prospołeczną i proekologiczną postawę inwestorów oraz stabilność długoterminowego inwestowania (po 13\% wskazań). Prezentowane wyniki wskazują na nadrzędność stopy zwrotu nad innymi zmiennymi. Jednakże poszerzanie oferty produktowej, potrzeba dywersyfikacji inwestycji oraz opinie innych inwestorów również determinują wzrost zainteresowania SRI.

Próbując dokonać oceny perspektywy rozwoju społecznie odpowiedzialnego inwestowania na polskim rynku kapitałowym, posłużono się okresem pięcioletnim (okres liczony od końca 2016 r.). W ocenie przyszłości SRI eksperci mogli posłużyć się takimi określeniami, jak szybki wzrost, wolny wzrost, constans, wolny spadek, szybki spadek oraz nie mam zdania. Eksperci w swoich odpowiedziach zawęzili wybór do trzech wariantów: szybki wzrost, wolny wzrost, constans. Większość 
z nich (75\%) wskazała na wolny wzrost społecznie odpowiedzialnego inwestowania w następnym pięcioleciu, co świadczy o umiarkowanym optymizmie w ocenie perspektyw rozwoju społecznie odpowiedzialnego inwestowania.
Wyższa stopa zwrotu niż z tradycyjnych produktów inwestycyjnych
Prospołeczne i prośrodowiskowe postawy inwestorów

Stabilność długoterminowego inwestowania

Wzrost oferty produktowej dotyczącej społecznie odpowiedzialnego inwestowania

Opinie innych inwestorów

Potrzeba dywersyfikacji portfela inwestycyjnego

Ulgi podatkowe dla inwestorów

Specjalistyczne doradztwo finansowe w zakresie społecznie odpowiedzialnego inwestowania

Ulgi podatkowe dla przedsiębiorstw

Moda na ten kierunek inwestycyjny

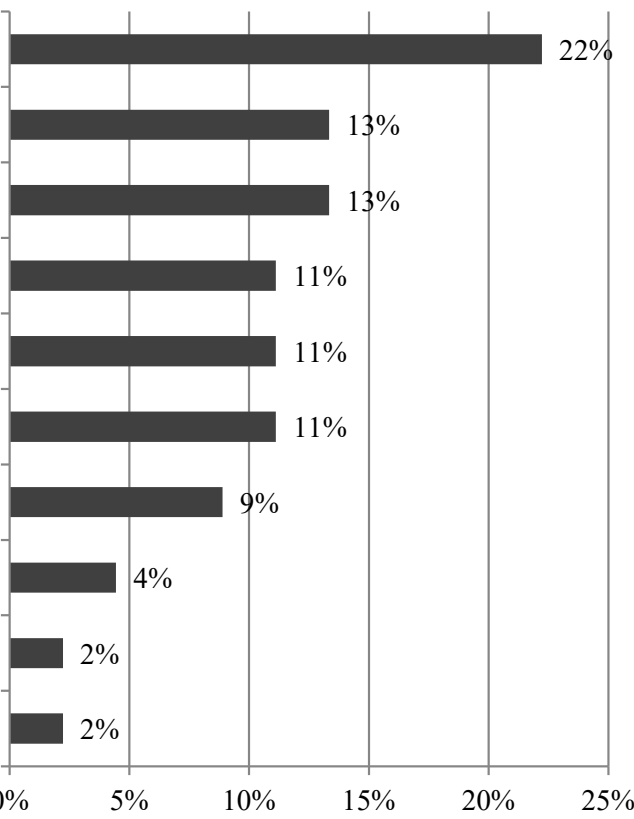

Rysunek 3. Czynniki wpływające na wzrost popytu ze strony inwestorów na społecznie odpowiedzialne produkty inwestycyjne w Polsce (wielokrotny wybór)

\section{Źródło: badanie własne}

Inwestycje społeczne (inwestycje z wpływem)

Strategia negatywna (wykluczenia)

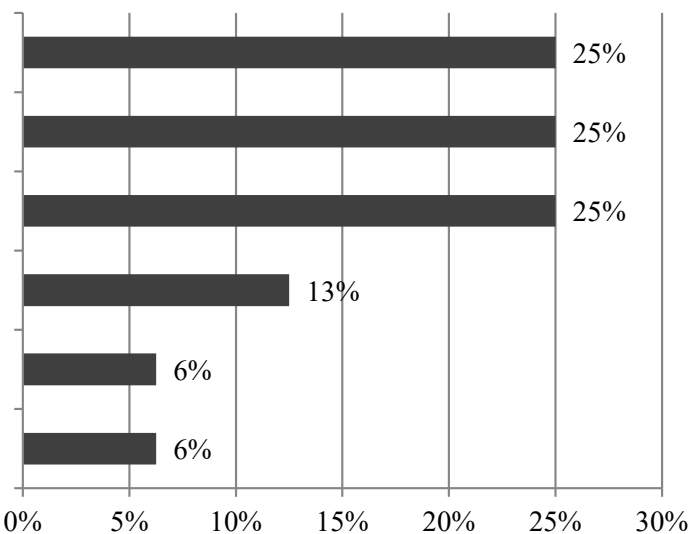

Rysunek 4. Rozkład odpowiedzi na pytanie: „Proszę wskazać społecznie odpowiedzialną strategię inwestycyjną, która Pana/Pani zdaniem będzie najczęściej wykorzystywana na rynku kapitałowym w Polsce w najbliższych 5 latach" (wybór jednokrotny)

Źródło: badanie własne 
Dostępność danych statystycznych o popularności strategii inwestycyjnych wykorzystywanych w ramach SRI przyczyniła się do zapytania ekspertów o to, która społecznie odpowiedzialna strategia inwestycyjna będzie najczęściej wykorzystywana na rynku kapitałowym w Polsce w najbliższych pięciu latach. Uzyskane wyniki przedstawiono na rysunku 3. Trzy z sześciu strategii zostały wskazane jako dominujące w przyszłości - inwestycje społeczne, strategia negatywna oraz integracja czynników ESG.

Nawiązując do danych przedstawionych w poprzedniej części artykułu, w okresie 2009-2015 najczęściej wykorzystywanymi strategiami inwestycyjnymi na polskim rynku kapitałowym były: strategia negatywna, selekcja na podstawie norm oraz strategia „najlepsze w swojej klasie”. Wskazania ekspertów reprezentują o wiele większe podejście do zainteresowania pozytywnymi strategiami, promującymi dobre praktyki i zaangażowanie we wdrażanie czynników ESG do procesów inwestycyjnych. Przykład stanowi wysoki odsetek wskazań strategii inwestycji społecznych.

\section{Podsumowanie}

Społecznie odpowiedzialne inwestowanie na współczesnym rynku finansowym jest ściśle związane z implementacją etyki do finansów. Tradycyjne produkty i usługi finansowe są konstruowane oraz udostępniane z uwzględnieniem kryteriów pozafinansowych. Te innowacyjne rozwiązania powoli implementowane są na polskim rynku finansowym.

Jak pokazują dane rynkowe, w Polsce corocznie wzrasta zaangażowanie w podejmowanie decyzji inwestycyjnych zgodnie z kryteriami ESG. Potwierdza ono rozszerzenie spektrum wykorzystywanych strategii inwestycyjnych, charakterystycznych dla społecznie odpowiedzialnego inwestowania. Przez indeks giełdowy, taki jak RESPECT Index, będący inicjatywą GPW w Warszawie, promowane są spółki publiczne stosujące standardy CSR. Z kolei polski rząd wprowadził zupełnie nowy produkt inwestycyjny w postaci ekologicznych obligacji. W wyniku wystosowania takiej oferty polski rynek finansowy nie powiela rozwiązań znanych na globalnym rynku finansowym, ale inicjuje nowy produkt, cieszący się dużym powodzeniem.

Zjawisko finansjalizacji pogłębia się przez kolejne innowacje finansowe, które odrywają system finansowy od gospodarki realnej. Innowacje produktowe, procesowe i organizacyjne, które związane są bezpośrednio ze społecznie odpowiedzialnym inwestowaniem, wyróżniają się długim horyzontem, podejściem w ocenie projektów inwestycyjnych rozszerzonym o czynniki pozafinansowe, co przyczynia się do redukcji ryzyka inwestycyjnego. Społecznie odpowiedzialne inwestowanie nie powinno być więc traktowane jako kolejna innowacja zwiększająca ekspan- 
sywność rynków finansowych. Wyniki zaprezentowanych empirycznych badań własnych wskazują na wzrost zainteresowania wykorzystywaniem pozytywnych strategii inwestycyjnych $\mathrm{w}$ ocenie projektów inwestycyjnych w ciągu najbliższych pięciu lat. Z kolei wśród czynników mających największe znaczenie w kreowaniu popytu inwestorów na społecznie odpowiedzialne produkty inwestycyjne w Polsce znajdują się: wyższa stopa zwrotu, prospołeczna, ekologiczna postawa inwestorów oraz stabilność długoterminowego inwestowania.

Przyszłość zrównoważonego rynku finansowego definiowana przez zmiany jakościowe napawa optymizmem, że szersza implementacja społecznie odpowiedzialnego inwestowania jest innowacją na miarę współczesnych wyzwań gospodarczych. Przedstawiony proces inwestowania stanowi przykład etycznych decyzji i działań w sektorze finansowym, który nie pogłębia dysproporcji, ale prowadzi do sprawiedliwej alokacji kapitału.

\section{Bibliografia}

Ambasada RP w Londynie (2017), Polska nagrodzona za emisję obligacji prośrodowiskowych, https://londyn.msz.gov.pl/pl/aktualnosci/polska_nagrodzona_za_emisje_obligacji_prosrodowiskowych?channel=www [dostęp: 6.03.2017].

Antoszkiewicz J. (1990), Metody heurystyczne. Twórcze rozwiąywanie problemów, Polskie Wydawnictwo Ekonomiczne, Warszawa.

Carrots \& Sticks. Global trends in sustainability reporting regulation and Policy (2016), KPMG International, GRI, United Nations Environment Programme, The Centre for Corporate Governance in Africa.

Dziawgo L. (1998), Pozyskiwanie kapitałów osób fizycznych na rynku finansowym w celu ochrony środowiska naturalnego, Wydawnictwo UMK, Toruń.

EconomyWatch (2017), http://www.economywatch.com/economic-statistics/theWorld/GDP_Current_Prices_US_Dollars/ [dostęp: 20.05.2017].

Epstein G. (2001), Financialization, Rentier Interests, and Central Bank Policy, Department of Economics and Political Economy Research Institute (PERI), University of Massachusetts, Amherst.

Eurosif(2010), European SRI Study 2010, http://www.eurosif.org/sri-study-2010 [dostęp: 30.06.2017]. Eurosif(2012), European SRI Study 2012, http://www.eurosif.org/sri-study-2012 [dostęp: 30.06.2017]. Eurosif (2014), European SRI Study 2014, http://www.eurosif.org/sri-study-2014 [dostęp: 30.06.2017].

Eurosif(2016), European SRI Study 2016, http://www.eurosif.org/sri-study-2016 [dostęp: 30.06.2016].

Frame W. S., White L. J. (2004), Empirical Studies of Financial Innovation: Lots of Talk, Little Action?, „Journal of Economic Literature”, t. 42(1), s. 116-144, https://www.aeaweb.org/article s?id=10.1257/002205104773558065 [dostęp: 28.06.2017].

Gollier C., Pouget S. (2012), Asset prices and corporate behavior with socially responsible investors, „Technical report”, IDEI, Geneva.

Gompers P., Ishii J., Metrick A. (2003), Corporate governance and equity price, „Quarterly Journal of Economics", nr 118, s. 107-155.

GPW (2017), https://www.gpw.pl/indeks?isin=PL9999999540\#Portfolio [dostęp: 22.12.2017].

Gregorczyk D. (2015), Raportowanie zintegrowane w tworzeniu wspólnej wartości (CSV), „Prace Naukowe Uniwersytetu Ekonomicznego we Wrocławiu", nr 396, s. 59-66. 
Hong H., Kacperczyk M. (2009), The price of sin: The effect of social norms on markets, „Journal of Financial Economics", nr 93, s. 15-36.

Hsu Ch., Sandford B. (2007), The Delphi Technique: Making Sense of Consensus, „Practical Assessment Research \& Evaluation”, t. 12(10), s. 1-8, http://pareonline.net/getvn.asp?v=12\&n=10 [dostęp: 7.11.2016].

International Finance Corporation (2017), Social Bonds Introduction and Impact Report, World Bank Group, Washington.

Jedynak T. (2016), Fundusze inwestycyjne na rynku inwestycji społecznie odpowiedzialnych, „Zeszyty Naukowe UEK w Krakowie", nr 2(950), s. 23-40, http://dx.doi.org/10.15678/ZNUEK.2016.0950.0202.

Jędrych E. (2013), Inwestowanie w innowacje społeczne w organizacjach gospodarczych, Wydawnictwo Naukowe PWN, Warszawa.

Kinder P. (2005), Socially responsible investing. An evolving concept in a changing world, KLD, Boston.

Kłobukowska J. (2014), Społecznie odpowiedzialne inwestowanie na rynku europejskim, „Zeszyty Naukowe SGGW. Polityki europejskie, Finanse i Marketing", nr 11(60), s. 78-89.

Kłobukowska J. (2015), Społecznie odpowiedzialne innowacje przedsiębiorstw, „Pieniądze i Więź”, nr 3(68), s. 62-70.

Kłobukowska J. (2017), Społecznie odpowiedzialny rynek finansowy w Polsce-podązając za światowym trendem w wymiarze ESG, „Transformacje”, nr 1-2(92-93), s. 106-115.

Ministerstwo Finansów (2016), Polska pierwszym państwem emitujacym zielone obligacje, https://www.mf.gov.pl/ministerstwo-finansow/dla-mediow/informacje-prasowe/-/asset_publisher/6PxF/content/id/5855504 [dostęp: 12.12.2016].

Money (2016), Polska wyemitowała ,zielone” obligacje. Wielkie zainteresowanie inwestorów, http:// www.money.pl/gospodarka/wiadomosci/artykul/zielone-obligacje-polska-emisja-green-bonds, 168,0,2217384.html [dostęp: 15.12.2016].

Schueth S. (2003), Socially Responsible Investing in the United States, „Journal of Business Ethics", nr 43, s. 189-194, https://doi.org/10.1023/A: 1022981828869.

Schumpeter J.A. (1960), Teoria rozwoju gospodarczego, Wydawnictwo PWE, Warszawa.

Sparkes R. (2002), Socially Responsible Investment - A Global Revolution, John Wiley \& Sons, Chichester.

Statman M. (2006), Socially Responsible Indexes, „The Journal of Portfolio Management”, nr 32(3), s. $100-109$.

Tufano P. (2003), Financial Innovation, [w:] G. M. Constantinides, M. Harris, R.M. Stulz (eds.), Handbook of the Economics of Finance, t. 1, część 1, Harvard Business School, Elsevier, Amsterdam. 


\title{
Socially Responsible Investment As an Innovation on the Financial Market in Poland in the Time of Financialisation - Present State and Perspectives
}

\begin{abstract}
The main aim of the article is to identify the factors distinguishing socially responsible investment (SRI) as an innovation on the financial market as well as the presentation of development prospects of SRI in Poland. In the course of goal realization were discussed definitions of sustainable financial market, socially responsible investment and analyzed SRI according to characteristics of financial innovation. Selected aspects of SRI, such as the RESPECT Index or green bonds, are examples of innovations on the Polish financial market. As part of the analysis of the prospects of socially responsible investment in Poland, author presents the results of empirical research conducted in 2017 in accordance to the Delphi method which indicate the slow growth of SRI in the next five year perspective.
\end{abstract}

Keywords: financial innovation, socially responsible investment, green bond, RESPECT Index, finansialisation

JEL: M14, Q01, 016

\begin{tabular}{|c|c|}
\hline \multirow[t]{2}{*}{ OPEN ACCESS } & $\begin{array}{l}\text { (C) by the author, licensee Łódź University - Łódź University Press, Łódź, Poland. } \\
\text { This article is an open access article distributed under the terms and conditions } \\
\text { of the Creative Commons Attribution license CC-BY } \\
\text { (http://creativecommons.org/licenses/by/3.0/) }\end{array}$ \\
\hline & Received: 2017-11-04; verified: 2018-10-02. Accepted: 2018-11-22 \\
\hline
\end{tabular}

